http://dx.doi.org/10.12775/szhf.2017.044

\author{
TAdeusz PabJan \\ Uniwersytet Papieski Jana Pawea II w Krakowie, Kraków, Polska \\ e-mail: tadeusz.pabjan@upjp2.edu.pl
}

\title{
Gottfrieda W. Leibniza idea świata najlepszego z możliwych
}

Jednym z najciekawszych, ale zarazem najbardziej kontrowersyjnych pomysłów niemieckiego filozofa Gottfrieda Wilhelma Leibniza (1646-1716) jest koncepcja, zgodnie z którą Bóg powołuje do istnienia najlepszy z możliwych światów. Intuicja dotycząca tego, że zło fizyczne i moralne nie jest sprzeczne $\mathrm{z}$ ideą najlepszego świata, pojawia się $\mathrm{w}$ wielu dziełach tego autora i znajduje w nich różnorakie uzasadnienie. Problemem tym Leibniz zajął się już w jednej z pierwszych swoich prac - w Wyznaniu wiary filozofa opublikowanym w roku 1673. Dopiero jednak pod koniec swojego życia zagadnienie to poddał systematycznej i dogłębnej analizie, poświęcając mu obszerny traktat zatytułowany Teodycea o dobroci Boga, wolności człowieka i pochodzeniu $z \nmid a^{1}$, opublikowany w roku 1710 . Termin „teodycea” jest neologizmem utworzonym z greckich słów Theos (Bóg) i dike (sąd, sprawiedliwość), i choć pojawia się w tytule tego dzieła, to ani razu nie występuje w samym tekście. Może on oznaczać doktrynę sprawiedliwości Bożej albo doktrynę usprawiedliwienia Boga. Sam Leibniz skłaniał się ku pierwszej z tych dwóch interpre-

${ }^{1}$ Dzieło to zostało opublikowane po raz pierwszy w roku 1710 jako Théodicée sur la bonté de Dieu, la liberté de l'homme et l'origine du mal. Na karcie tytułowej pierwszego wydania nie było nazwiska Leibniza, dlatego też przez pewien czas sądzono, że „Teodycea” to pseudonim autora. 
tacji, jednak nie był w tym do końca konsekwentny, bo w przedmowie do Teodycei zaznaczał, że jego zamiarem jest „bronienie sprawy Bożej”, „przeprowadzenie apologii doskonałości Boga”, wykazywanie „dlaczego zło ma inne źródło niż wola Boga” i zwalczanie błędów "tych, którzy oskarżali Boga” o to, że jest odpowiedzialny za zło obecne w świecie ${ }^{2}$. O tym, że właśnie w taki sposób - jako obronę Boga przed zarzutem zła - Leibniz postrzegał zadanie, którego podjąl się, pisząc Teodyceę, może świadczyć również tytuł, jakim on sam opatrzył wydane osobno łacińskie streszczenie tego dzieła: „Sprawa Boga broniona przez wskazanie na Jego sprawiedliwość”3. W krótkim czasie upowszechniło się właśnie takie rozumienie terminu „teodycea” - pod tym określeniem zaczęto rozumieć dyscyplinę z pogranicza filozofii i teologii, zajmującą się obroną Boga przed zarzutem obecnego w stworzonym świecie zła, które jawi się jako jeden najmocniejszych argumentów przemawiających przeciwko Bożej dobroci, sprawiedliwości i wszechmocy.

\section{Okoliczności powstania Teodycei}

Bezpośrednim impulsem do napisania Teodycei była dla Leibniza działalność filozofa i publicysty Pierre’a Bayle’a, który w roku 1697 wydał Słownik historyczny i krytyczny zawierający encyklopedyczne omówienie poglądów postaci znanych $\mathrm{z}$ historii filozofii i teologii. Bayle był wolnomyślicielem, który miał talent do krytycznego analizowania referowanych przez siebie koncepcji i precyzyjnego ukazywania ich ułomności. Analizy te były naznaczone wyraźnym sceptycyzmem autora, który nie krył swego agnostycyzmu - zwłaszcza wtedy, gdy omawiał zagadnienia teologiczne. Bayle podawał w wątpliwość istnienie boskiej opatrzności nad światem i dowodził, że nie można pogodzić z sobą tezy o istnieniu wszechmocnego i dobrego Boga oraz doświadczanego empirycznie faktu zła. Wykazywał również - odwołując się m.in. do nauk Zaratustry głoszącego odwieczną walkę dwóch pierwotnych zasad, tzn. dobra i zła - że nie jest możliwe obalenie manichejskiego wyja-

${ }^{2}$ Zob. G. W. Leibniz, Teodycea. O dobroci Boga, wolności człowieka i pochodzeniu zła, przeł. M. Frankiewicz, Warszawa 2001, s. 9, 22-23.

${ }^{3}$ Causa Dei asserta per iustitiam Eius; tytuł tego dziełka jest w rzeczywistości nieco dłuższy w polskim przekładzie M. Frankiewicz (G. W. Leibniz, Pisma z teologii mistycznej, Kraków 1994, s. 91-124) został on oddany następująco: Przyczyna pochodzaca od Boga, potwierdzona przez Jego sprawiedliwość oraz zgodnie z nią połączone pozostałe doskonałości i ogół działań. 
śnienia natury zła. Nic dziwnego, że takie poglądy przykuły uwagę Leibniza, który postanowił napisać dzieło polemiczne, zawierające argumenty przemawiające przeciwko interpretacji Bayle'a.

Do powstania Teodycei przyczyniły się również inne okoliczności związane $\mathrm{z}$ tym, że Leibniz w okresie tworzenia tego dzieła pełnił rolę dworskiego dyplomaty i filozofa na dworze króla pruskiego Fryderyka I, którego żona Zofia Karolina - znała kontrowersyjne poglądy Bayle’a. Gdy królowa dała wyraz swemu zainteresowaniu tym, czy Leibniz potrafiłby odeprzeć argumenty zawarte w pracy Bayle’a, stało się jasne, że odpowiedź nie ograniczy się jedynie do kilku zdawkowych wyjaśnień, ale przyjmie postać obszernej monografii. Nie chodziło w tym przypadku jedynie o to, że życzenie królowej miało dla nadwornego filozofa rangę rozkazu. Leibniz potraktował to zadanie w kategoriach osobistego wyzwania, które - choćby ze względów ambicjonalnych - należało zrealizować najlepiej jak tylko można. Nie bez znaczenia było również i to, że jego filozoficzne poglądy - w szczególności zaś koncepcja harmonii przedustawnej ${ }^{4} \mathrm{i}$ idea świata najlepszego $\mathrm{z}$ możliwych, w którym „wszystko kończy się dobrze dla dobrych, a źle dla złych” - dobrze wpisywały się w społeczno-polityczny kontekst tamtej epoki: były one swego rodzaju odpowiedzią na „ideologiczne zapotrzebowanie warstw rządzących” i stanowiły „filozoficzną apoteozę istniejących warunków społecznych”. Nic dziwnego, że życzenie Zofii Karoliny zostało spełnione, choć ona sama nie doczekała ukończenia i wydania dzieła (zmarła w roku 1705). Okoliczności pracy nad Teodycea dobrze oddaje następujący fragment listu Leibniza skierowanego do teologa Thomasa Burnetta: „Większa część dzieła została złożona z różnych urywków wówczas, gdy przebywałem na dworze zmarłej Królowej Prus, gdzie często roztrząsano te kwestie w nawiązaniu do Słownika i innych dzieł Pana Bayle’a, które często były tutaj czytane. Moim zadaniem podczas dyskusji było odpowiadać na zarzuty Pana Bayle’a i ukazywać Królowej, że nie są one tak silne, jak chcą wierzyć niektórzy ludzie niezbyt przychylnie nastawieni do religii. Jej Królewska Mość bardzo często polecała mi sporządzanie odpowiedzi na piśmie, aby mogła je uważnie przemyśleć. Po śmierci tej wielkiej władczyni zebrałem owe kawałki i uzupełniłem radami przyja-

\footnotetext{
${ }^{4}$ Zgodnie z tą koncepcją stworzony przez Boga świat jest uporządkowaną całością - pomimo tego, że tworzące go podstawowe elementy (monady) nie oddziałują na siebie. Jest to możliwe dlatego, że monady funkcjonują jak zegary, które w momencie stworzenia zostały przez Boga zsynchronizowane, i dlatego obecnie działają w sposób zgodny, choć nie mają ze sobą żadnego kontaktu.

${ }^{5}$ Zob. R. Palacz, Klasycy filozofii, Warszawa 1987, s. 138.
} 
ciół wtajemniczonych w mój zamysł, z czego powstało wspomniane dzieło [...]. Ponieważ od młodzieńczych lat rozmyślałem nad tymi kwestiami, stąd ośmielam się twierdzić, że je omówiłem dogłębnie"6.

Dodatkowym czynnikiem, który miał wpływ na wytężoną pracę Leibniza nad Teodycea było to, że w swoich kolejnych publikacjach Bayle wprost poddał krytyce jego własne poglądy, m.in. koncepcję harmonii przedustawnej i związane z nią wyjaśnienie relacji zachodzącej pomiędzy duszą i ciałem. Leibniz odpowiadał na tę krytykę krótkimi artykułami polemicznymi ${ }^{7}$, ale były one jedynie zapowiedzią tego, co miało się pojawić w Teodycei. Trudność polegała jednak na tym, że realizacja tego dzieła domagała się systematycznego opracowania złożonego zagadnienia, któremu należało nadać postać obszernego traktatu, tymczasem Leibniz nie miał daru do pisania książek. Większość swoich pomysłów zamykał w prywatnych listach albo różnego rodzaju krótkich tekstach, które za jego życia nie były publikowane, i które ujrzały światło dzienne dopiero po jego śmierci. Nic dziwnego, że gdy w roku 1710 Leibnizowi udało się wreszcie ukończyć i opublikować Teodyceę, dzieło to przez długi czas było traktowane jako główne źródło informacji o poglądach filozofa z Hanoweru. Biorąc pod uwagę niezbyt udaną formę tego opracowania, okoliczność tę uznaje się dosyć często za niefortunny zbieg okoliczności. Gdy bowiem w XIX wieku zaczęto odkrywać w archiwach niepublikowane wcześniej rękopisy Leibniza, okazało się, że w wielu z nich myśl tego autora wyrażona jest w sposób o wiele bardziej jasny, precyzyjny i literacko atrakcyjny. Taka interpretacja, sugerująca, że Teodycea jest dziełem mało istotnym w porównaniu $\mathrm{z}$ innymi pracami Leibniza, nie jest jednak słuszna; w rzeczywistości bowiem to wszystkie pozostałe publikacje tego autora można potraktować jako zbiór uzupełnień i dopisków do Teodycei. To właśnie z tego powodu zachodzi tak wyraźny związek pomiędzy metafizyką Leibniza (jej najważniejsze tezy zostały wyrażone m.in. w Rozprawie metafizycznej i Monadologii) i jego koncepcją obrony Boga przedstawioną na kartach Teodycei. Aby zrozumieć zawarte tam argumenty, które przemawiają za tym, że Stwórca powołał do istnienia najlepszy z możliwych światów, należy wziąć poprawkę na sposób, w jaki Leibniz uzasadnia najważniejsze tezy swojej metafizyki ${ }^{8}$.

${ }^{6}$ List Leibniza do Thomasa Burnetta z 30 października 1710 r., [w:] Die philosophischen Schriften von G. W. Leibniz, red. C. I. Gerhardt, Berlin 1875-1890, t. III, s. 321.

${ }^{7}$ Zob. Die philosophischen Schriften von G. W. Leibniz, dz. cyt., t. IV, s. 517-524; 554-571.

${ }^{8}$ Por. P. Gut, Leibniz. Myśl filozoficzna XVII wieku, Wrocław 2004. 


\section{Świat optymalny, ale nie idealny}

Jedną z podstawowych zasad, które według Leibniza decydują o poprawności każdego rozumowania, jest zasada racji dostatecznej. Odpowiada ona za to, iż „uznajemy, że żaden fakt nie może okazać się prawdziwy, czyli istniejący, żadna wypowiedź słuszna, jeśli nie ma racji dostatecznej, dlaczego jest tak, a nie inaczej" ${ }^{\prime \prime}$ Zasada ta, odniesiona do faktu istnienia świata, domaga się wyjaśnienia tego, dlaczego świat istnieje i dlaczego jest taki, a nie inny. W przygodnych bytach tworzących ten świat tego typu racji dostatecznej znaleźć nie można, dlatego musi ona znajdować się poza nimi - musi być bytem koniecznym, a zarazem niezmiennym, rozumnym, nieskończonym, doskonałym i zawierającym w sobie wszystkie możliwości ${ }^{10}$. Taki byt w tradycji filozoficznej określany jest mianem Absolutu, a teologia nazywa go Bogiem. Według Leibniza działanie Boga, który stanowi rację dostateczną stworzonego świata, odznacza się absolutną koniecznością, przy czym jest to konieczność nie tylko „metafizyczna”, ale również „logiczna”, a niekiedy nawet "geometryczna”" ${ }^{11}$ Oznacza to, że akt stworzenia świata, który teologia za św. Tomaszem wyjaśnia jako ontyczną zależność pomiędzy Bogiem i tym, co stworzone, można rozumieć w kategoriach matematycznego działania, prowadzącego do powstania realnie istniejącej rzeczywistości. Tę intuicję można odnaleźć w kilku różnych pismach Leibniza, natomiast on sam najwyraźniej wypowiedział ją w następującym zdaniu zapisanym na marginesie jednego ze swoich tekstów: „Gdy Bóg liczy i zamyśla, świat się staje” ${ }^{12}$. W wyniku tego „liczenia i zamyślania” dokonywanego przez Stwórcę zaczyna istnieć świat, który jest maksymalnie racjonalny, i w którym nie ma niczego, co nie miałoby swojej racji dostatecznej, i co byłoby bez uzasadnienia ${ }^{13}$. Dla ograniczonego ludzkiego umysłu racje dostateczne nie zawsze są łatwe do uchwycenia - ze względu na to, że łańcuchy związków przyczynowo-skutkowych bardzo często są nieskończenie długie. Nie jest to jednak żadnym problemem dla Boga, „który jako jedyny jednym duchowym wejrzeniem obejmuje nieskończony łańcuch następstw”14. Bóg nie musi zatem dedukować ani domyślać się tego,

\footnotetext{
${ }_{9}^{9}$ G. W. Leibniz, Monadologia, [w:] tenże, Pisma z teologii mistycznej, s. 81.

${ }^{10}$ G.W. Leibniz, Teodycea, s. 124-125.

11 Tamże, s. 21.

${ }_{12}$ Zob. Die philosophischen Schriften von G. W. Leibniz, t. VII, s. 190-193.

${ }^{13}$ Por. M. Heller, Ostateczne wyjaśnienia wszechświata, Kraków 2008, s. 193-201.

${ }^{14}$ G. W. Leibniz, O przypadkowości, [w:] tenże, Pisma z teologii mistycznej, s. 51.
} 
w jaki sposób będzie przebiegać następstwo przyczyn i skutków w stworzonym świecie, ale uwzględnia jednocześnie wszystkie możliwości i dostrzega wszystkie logiczne związki zachodzące pomiędzy poszczególnymi elementami całości. W tym kontekście Leibniz mówi o nieskończenie wielu „możliwych światach"15. Każdy z tych światów określony jest przez jedną z możliwych - logicznie niesprzecznych - konfiguracji zdarzeń, które składają się na historię stworzonej przez Boga rzeczywistości. Zbiór tych nieskończenie wielu konfiguracji istnieje potencjalnie w Bożym umyśle, i tylko jedna z nich uzyskuje przywilej realnego zaistnienia. Jakim kryterium kieruje się Stwórca, wybierając właśnie tę, a nie inną możliwość? Odpowiedź na to pytanie dla Leibniza jest oczywista - Bóg, który jest samą mądrością i dobrocią, z niekończonego zbioru wszystkich możliwości nie może wybrać niczego innego niż to, co najlepsze: „jest niezliczona wielość możliwych światów, z których Bóg musiał wybrać najlepszy, ponieważ nie czyni niczego, nie kierując się najwyższym rozumem"16.

Optymizm zawarty w tezie głoszącej, iż Bóg stwarza najlepszy ze wszystkich możliwych światów, już w czasach Leibniza spotkał się ze zrozumiałym sceptycyzmem, który najdosadniej został wyartykułowany przez Woltera. W niewielkim dziełku Kandyd ${ }^{17}$, będącym swego rodzaju odpowiedzią na koncepcję Leibniza, autor ten wylicza najważniejsze przejawy zła obecnego w świecie, i stawia pytanie, które do dziś powtarzają z upodobaniem krytycy tej idei: jeśli to jest najlepszy z możliwych światów, to jak wyglądają te gorsze ${ }^{18}$ Kpina zawarta $w$ tym pytaniu świadczy jednak o niezrozumieniu intencji Leibniza, i powierzchownym potraktowaniu jego argumentu. Autor Teodycei nie miał bowiem wątpliwości co do tego, że w stworzonym przez Boga świecie istnieje zło. Sądził jednak, że jest ono w pewnym sensie koniecznym elementem całości. Świat najlepszy z możliwych nie jest bowiem światem idealnym, który byłby najlepszy w sensie absolutnym i bezwzględnym dla każdego z tworzących go elementów - taki świat istnieć nie może, bo sama jego idea jest czymś wewnętrznie sprzecznym, a zgodnie z respekto-

${ }^{15}$ „Swiatem nazywam cały ciąg i cały zbiór wszystkich istniejących rzeczy, aby nie mówiono, że kilka światów może istnieć w różnych czasach i w różnych miejscach. Trzeba by bowiem zaliczyć je wszystkie razem do jednego świata lub jeśli ktoś woli - do jednego wszechświata";

G. W. Leibniz, Teodycea, s. 126.

16 Tamże, s. 126.

${ }^{17}$ Wolter, Kandyd czyli optymizm, przeł. T. Żeleński-Boy, Kraków 2009.

${ }^{18}$ „Kandyd, przerażony, oszołomiony, odurzony, cały zakrwawiony i drżący, powiada sam do siebie: 'Jeżeli to jest najlepszy z możliwych światów, jakież są inne?'”, tamże, s. 15. 
waną przez Leibniza zasadą niesprzeczności sprzeczność jest nicością, i z tej racji istnieć nie może. Bóg nie mógł zatem stworzyć świata idealnego, ale musiał dokonać wyboru najbardziej optymalnego układu dobrych i złych elementów, które będą tworzyć strukturę świata realnie istniejącego. Musiał wybierać ze zbioru światów, z których żaden nie jest całkowicie doskonały, to znaczy zupełnie pozbawiony elementu zła.

Stworzona przez Boga rzeczywistość jest zatem najlepszym ze wszystkich światów możliwych, bo Stwórca, kierując się "najwyższym rozumem”, widzi wszystkie możliwe ciągi przyczyn i skutków, i z całego spektrum tych możliwości wybiera tę, w której realizuje się najwięcej dobra. Akt stwórczy przypomina tu poniekąd pracę matematyka, który „liczy i zamyśla”, badając przebieg funkcji i znajdując optymalne rozwiązanie analizowanego zagadnienia: „Najwyższa mądrość w połączeniu z dobrocią, która jest tak samo nieskończona, mogła wybrać jedynie to, co najlepsze. Bo jak mniejsze zło jest pewnego rodzaju dobrem, tak samo mniejsze dobro jest pewnego rodzaju złem, jeżeli staje na przeszkodzie o wiele większemu dobru. Toteż należałoby coś poprawić w Bożych działaniach, gdyby istniał sposób, aby zrobić lepiej. W matematyce, gdy nie ma maksimum ani minimum, czyli niczego wyróżnionego, wszystko przebiega jednakowo lub, jeżeli to niemożliwe, nie dzieje się nic. Tak samo można powiedzieć na temat równie dobrze zorganizowanej jak matematyka doskonałej mądrości, że gdyby nie było najlepszego (optimum) spośród wszystkich możliwych światów, Bóg nie stworzyłby żadnego świata"19.

Leibniz nie przez przypadek odwołuje się tu do porównania zaczerpniętego z matematyki. Stwórcze działanie Boga jest bowiem podobne do rozwiązywania wyjątkowo trudnego równania $\mathrm{z}$ nieskończoną liczbą zmiennych, które ma na celu otrzymanie wyniku oznaczającego optymalną konfigurację dobrych i złych zdarzeń składających się na historię stworzonego świata. Ponieważ równanie to rozwiązuje Bóg, który jest matematykiem doskonałym, wszechmocnym i absolutnie dobrym, nie jest możliwe to, by mógł otrzymać wynik niepoprawny, to znaczy nie prowadzący do stanu optymalnego. Powstający $\mathrm{w}$ efekcie tego działania świat - warto $\mathrm{w}$ tym miejscu jeszcze raz przypomnieć słowa Leibniza o tym, że świat „staje się” wtedy, gdy Bóg „liczy i zamyśla" - musi zatem być realizacją najlepszej możliwości. Jest to świat optymalny w tym sensie, że zawiera maksymalną ilość możliwego dobra przy minimalnej ilości nieuniknionego zła. Znany fizyk Max Planck zauważył, że

${ }^{19}$ G.W. Leibniz, Teodycea, s. 125-126. 
tej intuicji Leibniza można nadać ciekawą interpretację fizykalną: warunek, którym kierował się Stwórca powołujący świat do istnienia, ma postać zasady najmniejszego działania, w której „nieuniknione splecenie dobra i zła odgrywa rolę zadanych warunków”, i z której wynikają „wszystkie własności rzeczywistego świata" ${ }^{20}$. Oczywiście matematyczne opisanie tych warunków i wyliczenie tych własności jest zadaniem przekraczającym możliwości ograniczonego ludzkiego umysłu, ale nie jest to żadnym problemem dla Boga, który ma pełną i absolutnie pewną wiedzę na temat wszystkich parametrów koniecznych do rozwiązania tego zadania.

Świat idealny, w którym każdy byt miałby zapewnione każde możliwe dobro, nie może istnieć dlatego, że byty wchodzące w skład dowolnego ze światów możliwych są od siebie wzajemnie zależne. Świat jest strukturą złożoną z elementów powiązanych siecią różnych relacji, w której dobro jednego elementu jest zawsze ograniczone dobrem wszystkich innych, sąsiadujących elementów. Każde zdarzenie zachodzące w dowolnym miejscu i czasie każdego ze światów możliwych ma bowiem nieuniknione konsekwencje dla wszystkich innych zdarzeń składających się na historię tego świata, i wszystkich innych bytów, które $\mathrm{w}$ tych zdarzeniach uczestniczą. Leibniz wyjaśnia charakter tej zależności, odwołując się do geometrycznych intuicji: „Trzeba bowiem wiedzieć, że wszystko jest wzajemnie połączone w każdym z możliwych światów. Każdy wszechświat to podobnie jak ocean jednolita całość. Najmniejszy ruch rozszerza swoje oddziaływanie na dowolną odległość, chociaż to oddziaływanie staje się w miarę odległości mniej odczuwalne"21. Komentując ten fragment Teodycei, Michał Heller podkreśla, że to właśnie wzajemna zależność wszystkich elementów w każdym z możliwych światów decyduje o tym, iż mówiąc o świecie najlepszym z możliwych „można mówić tylko o świecie najlepszym ze względu na najbardziej optymalny układ całej relacyjnej sieci. Upraszczając, można powiedzieć, że chodzi o dobro całości przy minimalnym naruszeniu dobra poszczególnych elementów"22. Każdy ze światów możliwych jest zatem strukturą, w której dokonuje się nieuniknione zmieszanie dobra i zła. Główne zadanie Boga powołującego do realnego zaistnienia jeden z tych światów, polega na znalezieniu optymalnego rozwiąza-

${ }^{20}$ Zob. M. Planck, Zasada najmniejszego działania, [w:] tenże, Nowe drogi poznania fizycznego a filozofia, przeł. K. Napiórkowski, Warszawa 2003, s. 80.

${ }^{21}$ G. W. Leibniz, Teodycea, s. 126.

${ }^{22}$ M. Heller, Ostateczne wyjaśnienia wszechświata, s. 199. 
nia, w którym dobro każdego z elementów struktury jest pomniejszone tylko o tyle, o ile wymaga tego dobro całości.

\section{Zło obecne w najlepszym ze światów}

Argumenty Leibniza uzasadniającego swoją tezę o tym, że Bóg stworzył najlepszy z możliwych światów, przypominają swoim charakterem dowód ontologiczny św. Anzelma, który z samej idei Boga jako bytu absolutnie doskonałego wyprowadza wniosek o Jego koniecznym istnieniu. Rozumowanie autora Teodycei jest podobne: skoro Bóg jest bytem absolutnie dobrym, mądrym i wszechmocnym, i skoro w Jego umyśle istnieją potencjalnie wszystkie możliwe do zrealizowania konfiguracje dobra i zła, to oczywiste jest to, że zostaje przez Niego wybrana konfiguracja optymalna, i że właśnie ona jest powołana do istnienia. Wywód ten można przedstawić jeszcze krócej: skoro Bóg istnieje, to stworzony przez niego świat musi być światem najlepszym z możliwych. Wszystkie własności takiego świata wynikają bowiem w pewnym sensie $\mathrm{z}$ samego pojęcia Boga jako bytu absolutnie dobrego, mądrego i sprawiedliwego. „Jest zatem rzeczą z góry pewną i zawartą w samym pojęciu Bytu doskonałego - podsumowuje argumentację Leibniza Kołakowski - że żyjemy w najlepszym świecie, jaki można logicznie pomyśleć"23. W świecie stworzonym przez Boga nie może istnieć nic nieracjonalnego i nieuzasadnionego, bo sprzeciwiałoby się to naturze Stwórcy, który właśnie taki, a nie inny świat powołał do istnienia. Gdyby ten świat nie był najlepszym ze wszystkich możliwych światów, to oznaczałoby to, iż Bóg albo nie mógł mieć wyobrażenia takiego świata, albo nie mógł go stworzyć, albo nie chciał go stworzyć. Każda z tych trzech możliwości jest wykluczona przez przymioty Boga: pierwsza przez Jego mądrość i wszechwiedzę, druga przez wszechmoc, trzecia przez absolutną dobroć.

Stworzony przez Boga świat jest również najlepszy w tym sensie, że jest najpiękniejszy i najbardziej harmonijny, bo wszystko cokolwiek Stwórca powołuje do istnienia, musi być doskonale uporządkowane i harmonijne. Bóg postępuje bowiem jak roztropny architekt, który przed przystąpieniem do rozpoczęcia budowli wykonuje odpowiedni plan i uwzględnia absolutnie

\footnotetext{
${ }^{23}$ L. Kołakowski, Jeśli Boga nie ma..., Kraków 1988, s. 15.
} 
wszystko to, co będzie potrzebne do realizacji zamierzonego dzieła ${ }^{24}$. Obecne w świecie zło jest jednym $\mathrm{z}$ takich elementów, które Boski Architekt wkomponował w strukturę najlepszego z możliwych światów. Harmonia tej struktury jest tak wielka, że jakakolwiek zmiana musiałaby sprawić, że „poprawiony” świat przestałby być światem najlepszym. Wniosek ten - zdaniem Leibniza odnosi się również do cierpienia i wszystkich innych form zła, które wydają się sprzeczne z ideą najlepszego świata: „Mógłby być świat bez grzechu i bez cierpień. Nie zgadzam się jednak, że wówczas byłby on najlepszy. [...] Gdyby zabrakło najmniejszego zła, które zdarza się w świecie, nie byłby to już ten świat, uznany mimo wszystko za najlepszy przez Stwórcę, który go wybrał"25. Bóg nie może zmienić niczego na lepsze $\mathrm{w}$ stworzonym świecie również z tego powodu, że taka zmiana oznaczałaby, iż Stwórca wcześniej podjął niewłaściwą decyzję, powołując do istnienia właśnie ten, a nie inny świat. To zaś jest $\mathrm{z}$ góry wykluczone, bo Bóg jest bytem doskonałym, który nie może się mylić ani żałować raz podjętych decyzji.

Analizując różne formy zła obecnego w stworzonym przez Boga świecie, Leibniz podąża drogą wyznaczoną przez św. Augustyna i wielu aspektach tego zagadnienia powtarza jego argumenty. Podobnie jak Augustyn, zło metafizyczne, czyli skończoność i ograniczoność bytów stworzonych, autor Teodycei rozumie w sensie prywatywnym - jako pewien brak doskonałości przynależnej jedynie Bogu. Zło nie jest bytem lub istniejącą niezależnie zasadą; jest jedynie brakiem dobra, podobnie jak ciemność jest brakiem światła, a zimno - brakiem ciepła ${ }^{26}$. Ten rodzaj zła w żaden sposób nie zagraża idei najlepszego $\mathrm{z}$ możliwych światów, ponieważ stworzenie nie może być równie doskonałe jak Stwórca. Świat bytów przygodnych musi być ograniczony i niedoskonały, ale jednocześnie ograniczoność ta i niedoskonałość nie burzą harmonijnego porządku nadanego temu światu przez Boga, bo „harmonia jest jednością $\mathrm{w}$ wielości, a największa jest tam, gdzie jest najwięcej elementów, i to pozornie będących w nieładzie, a w rzeczywistości dziwnym jakimś sposobem sprowadzonych nieoczekiwanie do największej zgodności" ${ }^{27}$. W harmonijnym, najlepszym ze światów, niedoskonałości muszą być w różnym stopniu rozdzielone pomiędzy wszystkie stworzone byty, i żaden

\footnotetext{
${ }^{24}$ Zob. G. W. Leibniz, Teodycea, s. 179-180.

${ }^{25}$ Tamże, s. 126.

${ }^{26}$ Zob. tamże, s. 259.

${ }^{27}$ G. W. Leibniz, Wyznanie wiary filozofa, Rozprawa metafizyczna, Monadologia, Zasady natury i łaski, oraz inne pisma filozoficzne, przeł. S. Cichowicz, Warszawa 1969, s. 13.
} 
z nich nie powinien domagać się wyjaśnień, dlaczego zajmuje akurat ten albo inny stopień niedoskonałości w uporządkowanej strukturze całości.

Uzasadnienie tego, dlaczego stworzone przez Boga byty nie mogą być doskonałe, uzyskuje pod piórem Leibniza formę rozumowania podobnego do argumentacji, którą wcześniej posługiwał się m.in. św. Augustyn ${ }^{28}$ : „wszystkie byty są z Boga i z nicości. Ich właściwy byt pochodzi z Boga, ich niebyt - z nicości [...]. Żadne stworzenie nie może być bez niebytu, w przeciwnym razie byłoby Bogiem" ${ }^{29}$. Niedoskonałość wszystkich bytów przygodnych jest zatem konsekwencją samego aktu stworzenia, które dokonało się z nicości (ex nihilo). Nic dziwnego, że owa nicość w pewnym sensie wchodzi w ontyczną strukturę każdego bytu, i że tego „składnika” nie może zabraknąć w żadnej stworzonej rzeczy - bo inaczej ta rzecz byłaby samym Bogiem. W systemie Leibniza wszystko, co realnie istnieje, musi respektować zasadę niesprzeczności. Sprzeczność nie może istnieć, bo jest równoznaczna z nicością. Ale ponieważ „wszystkie byty są z Boga i z nicości”, więc sprzeczność nie może być całkowicie wyeliminowana $\mathrm{z}$ tego, co stworzone. Bóg, powołując do istnienia najlepszy z możliwych światów, ogranicza do minimum ten nieunikniony margines sprzeczności, i w strukturze tego świata uwzględnia „tyle rzeczywistości, ile tylko możliwe" ${ }^{30}$. Innymi słowy, stwarza świat, w którym jest najwięcej istnienia, a najmniej nicości.

Jeśli chodzi o grzech, czyli zło moralne, to jest ono ceną dobra, jaką jest wolność - jest konsekwencją wolnej woli, którą Bóg obdarzył człowieka. Stwórca oczywiście nie chce tej formy zła, ale przyzwala na jej istnienie, bo bez tego przyzwolenia człowiek nie byłby prawdziwie wolny, a najlepszy z możliwych światów utraciłby obecną harmonię. Leibniz przeciwstawia się tu koncepcji powszechnego determinizmu głoszonej przez Spinozę. Owszem, istnieje szereg ograniczeń, które determinują takie czy inne zachowania człowieka, ale istnieje w nim również obszar wolności, oznaczającej możliwość podejmowania wyboru tego, co lepsze. Wiele różnych racji może skłaniać człowieka do podjęcia takiej czy innej decyzji, ale do tego, by był on autentycznie wolny wystarcza, by jedna z tych racji „skłaniała, nie narzucając konieczności”31.

Zło fizyczne, którego najważniejszym przejawem jest cierpienie dotykające człowieka i wszystkie inne istoty żywe, jest następstwem zła moralnego

${ }^{28}$ Zob. Święty Augustyn, O naturze dobra, przeł. M. Maykowska, [w:] tenże, Dialogi i pisma filozoficzne, Warszawa 1954, s. 169-201.

${ }^{29}$ G. W. Leibniz, Prawdziwa Theologia Mystica, [w:] tenże, Pisma z teologii mistycznej, s. 15.

${ }^{30}$ G. W. Leibniz, Monadologia, s. 82.

${ }^{31}$ G. W. Leibniz, Teodycea, s. 155. 
i metafizycznego. Fizyczny ból jest doznaniem, które ma związek z ograniczeniami materii będącej budulcem wszystkich żywych organizmów. Cielesne doznania przeważnie są przyjemne, ale niekiedy muszą być również bolesne, zaś miara cierpień, które musi znosić dana jednostka, zależy od miejsca zajmowanego przez nią w harmonijnej całości stworzenia. Cierpienia nie są daremne, gdyż pozwalają lepiej odczuwać dobro, mogą również spełniać funkcję kary za popełnione zło albo środka wychowawczego, który zapobiega jeszcze większemu złu, albo przyczynia się do większego dobra: „Co się zaś tyczy cierpień, zwłaszcza spadających na dobrych ludzi, to uważać należy za pewne, że wychodzą im one na większe dobro i jest to prawdziwe nie tylko teologicznie, ale i fizycznie. [...] A w ogóle można powiedzieć, że cierpienia, zrazu złe, okazują się dobre w skutkach, ponieważ stanowią krótszą drogę do doskonałości" ${ }^{32}$. Co istotne, nawet najbardziej drastyczne przykłady zła fizycznego - zdeformowane, niezdolne do samodzielnego życia płody noworodków albo cierpienia ludzi kalekich, którzy muszą żyć z wrodzonymi defektami ciała - nie psują powszechnej harmonii najlepszego z możliwych światów. Tego typu przypadki są wyjątkami, które jedynie potwierdzają regułę. Leibniz po raz kolejny dostrzega tu wyraźną analogię z matematyką, w której „występują czasami pozorne nieprawidłowości”, ale „po ostatecznym zbadaniu mieszczą się one $\mathrm{w}$ wielkim porządku" ${ }^{33}$. Podobnie zło fizyczne: jego obecność $\mathrm{w}$ najlepszym $\mathrm{z}$ możliwych światów może wydawać się niezrozumiała, ale wynika to jedynie z ograniczenia ludzkiego rozumu, który nie jest w stanie dostrzec harmonii ustanowionej przez Boga w pierwotnym akcie stworzenia.

Nie mając możności przeniknięcia Bożego zamysłu i zrozumienia wszystkich racji, które skłoniły Stwórcę do przyzwolenia na to, by różne postaci zła występowały w najlepszym z możliwych światów, należy - zdaniem Leibniza - zaufać dobroci Boga i mocno wierzyć w to, że wszystko, co powołał do istnienia, jest najlepsze, najpiękniejsze i najbardziej sensowne. Skoro wszechmocny i absolutnie dobry Stwórca pozwolił na istnienie zła, to widocznie miał ku temu ważne powody, i dlatego należy zakładać, że również zło przyczynia się w jakiś sposób do powstawania tego, co lepsze i bardziej doskonałe. Ograniczony człowiek nie jest kompetentną instancją do tego, by oceniać Boże dzieło, bo brakuje mu odpowiedniej perspektywy - spogląda

${ }^{32}$ G. W. Leibniz, O ostatecznym źródle rzeczy, [w:] tenże, Główne pisma metafizyczne, przeł. S. Cichowicz, J. Domański, Toruń 1995, s. 92.

${ }^{33}$ Por. G. W. Leibniz, Teodycea, s. 342. 
na nie jak na gigantyczny obraz, który oglądany z bliska jawi się jako niezrozumiałe połączenie rozmazanych barw i niewyraźnych kształtów, i dopiero $\mathrm{z}$ odpowiedniej odległości ujawnia całe swoje piękno. Dopiero wtedy dla obserwatora staje się zrozumiały zamysł artysty, który wykorzystał całą paletę barw, by stworzyć wielkie arcydzieło ${ }^{34}$. Człowiek jest takim obserwatorem, który na razie nie może zobaczyć Bożego dzieła z pełnej perspektywy, i dlatego musi mu wystarczyć wiara w to, że jest to dzieło najpiękniejsze i najlepiej skomponowane, i że wszelka niedoskonałość, zło i cierpienie ostatecznie zostaje przezwyciężone przez niepojętą mądrość, dobroć i wszechmoc Boga. To właśnie te przymioty Stwórcy są gwarantem tego, że żyjemy w najlepszym z możliwych światów: „Nieskończona mądrość Wszechmocnego połączona z Jego niezmierzoną dobrocią sprawiła, że spośród wszystkich rzeczy nic nie będzie mogło stać się lepsze od tego, jakim zostało uczynione przez Boga. Inaczej mówiąc, wszystkie te rzeczy są doskonale zharmonizowane i w najwspanialszy sposób ze sobą współgrają [...]. A zatem ilekroć w dziełach Boga coś wydaje się zasługiwać na naganę, należy sądzić, że nie poznaliśmy tego wystarczająco, mądry zaś, który zrozumie, pomyśli, że z pewnością nie jest pożądane, aby coś mogło być lepsze. Stąd z kolei wynika, że nie ma większego szczęścia niż służba Pańskiemu dobru, która polega na tym, że Boga trzeba kochać ponad wszystko i całkowicie Mu ufać”35.

\section{Podsumowanie}

Argumenty Leibniza uzasadniającego swoją tezę o tym, że Bóg stworzył najlepszy z możliwych światów, w dużej mierze są odpowiedzią na kontrowersyjne poglądy Bayle’a, z którymi autor Teodycei polemizuje na kartach swojego dzieła. Dokładna prezentacja tych argumentów wymagałaby osobnej, obszernej monografii, w której należałoby szczegółowo prześledzić logikę wywodu Leibniza odnoszącego się do poszczególnych tez swojego oponenta. W tym miejscu nie jest jednak potrzebna szczegółowa analiza tej polemiki choćby z tego względu, że to, co zostało do tej pory powiedziane na temat sposobu, w jaki Leibniz uzasadnia swoje przekonania, w zupełności wystarcza, by zrozumieć charakter jego argumentacji, i by domyślić się, co jest za-

\footnotetext{
${ }^{34}$ Por. G. W. Leibniz, O ostatecznym źródle rzeczy, s. 90-91; tenże, Teodycea, s. 255.

${ }^{35}$ G. W. Leibniz, Pisma z teologii mistycznej, s. 101.
} 
warte w kolejnych częściach Teodycei. Dzieło to jest w gruncie rzeczy nie tyle wynikiem konstruktywnego poszukiwania przez Leibniza rozwiązania problemu zła, ile wygłoszoną przezeń mową w obronie Boga - mową, w której nie ma miejsca na żadne wątpliwości, bo na straży poprawności zawartego w niej rozumowania stoją zasady logiki, a wszystkie wnioski wydają się wynikać w sposób konieczny z przyjętych w punkcie wyjścia założeñ ${ }^{36}$. Optymizm Leibniza zawarty w tezie, że Bóg stworzył najlepszy z możliwych światów, $\mathrm{w}$ dużej mierze uzasadniony jest jedynie wiarą w to, iż na drodze czystej spekulacji dotyczącej natury Boga - który niejako z definicji musi być bytem absolutnie dobrym, wszechmocnym i sprawiedliwym - można znaleźć łatwe rozwiązanie problemu zła. W rzeczywistości bowiem trzonem argumentacji Leibniza jest tautologiczne rozumowanie: świat stworzony przez Boga jest światem najlepszym z możliwych, bo absolutnie dobry Bóg nie może stworzyć niczego, co nie byłoby najlepsze.

Trudność polega tu jednak na tym, że problem zła, którego to rozumowanie dotyczy, nie jest problemem czysto teoretycznym, ale również - a może przede wszystkim - zagadnieniem o charakterze egzystencjalnym. Wiąże się $\mathrm{z}$ nim bowiem nieuniknione pytanie o sens życia wypełnionego cierpieniem i wystawionego na nieuniknioną konfrontację z wszystkimi innymi formami zła obecnego w najlepszym ze światów. Takiego problemu nie da się wcisnąć $\mathrm{w}$ ramy systemu dedukcyjnego, $\mathrm{w}$ którym $\mathrm{z}$ przyjętych $\mathrm{w}$ punkcie wyjścia niepodważalnych aksjomatów można łatwo uzyskać jednoznaczne i pewne rozwiązanie. Poza tym - nawet gdyby taka możliwość istniała, to i tak nie miałaby ona wielkiej wartości dla tych, którzy sami doświadczają cierpienia. Oni muszą zmierzyć się osobiście z problem, który dla teodycei w wydaniu Leibniza jest jedynie trudnością o charakterze czysto teoretycznym. Człowieka cierpiącego nie interesuje spójność argumentów, które można wydedukować z tezy o dobroci i mądrości Boga - on chce wiedzieć, dlaczego musi doświadczać destrukcyjnej mocy zła. Teoretyczne uzasadnienia przestają w tej perspektywie odgrywać jakąkolwiek rolę, bo nie dają odpowiedzi na pytanie o sens egzystencji naznaczonej cierpieniem. W tym sensie Teodycea Leibniza jawi się jako zgrabny zestaw rozumowych argumentów, które są dobrym materiałem do sprawdzania poprawności rozumowania dedukcyjnego, ale w niewielkim stopniu mogą pocieszyć tych, którzy sami doświadczają zła, i którzy muszą znaleźć siłę do znoszenia i przezwyciężenia cierpienia w swoim

${ }^{36}$ Por. J. Kopania, Siła dedukcji i słabość człowieka. Tragiczny optymizm Leibniza, [w:] G. W. Leibniz, Teodycea, s. XXI-XXIII. 
życiu. Dla nich analizy Leibniza przedstawiają taką wartość, jak dla człowieka głodnego i spragnionego odczyt o potrzebie zbilansowanego odżywiania ${ }^{37}$.

W całej argumentacji Leibniza najtrudniejsze do zaakceptowania wydaje się stwierdzenie, że każde, nawet najmniejsze zło, obecne w stworzonym przez Boga świecie, jest konieczne do tego, by świat ten był realizacją najlepszej ze wszystkich możliwości. Paradoksalność tego wniosku dobrze podkreśla sugestywne pytanie podobne do tych, które Wolter postawił po tragicznym trzęsieniu ziemi w Lizbonie $\mathrm{w}$ roku $1755^{38}$ : a więc bez trzęsień ziemi, powodzi, chorób zakaźnych i wszystkich innych form zła świat rzeczywiście byłby gorszy? Kołakowski trafnie zauważa, że takie pytania jest jednak źle postawione, bo zdaje się sugerować, że zwolennik tezy o najlepszym ze światów powinien przeniknąć zamysł Boga, który potrafi obliczyć optymalną proporcję pomiędzy dobrem i złem, i przewidzieć wszystkie konsekwencje każdego zdarzenia. Leibniz jednak wcale nie twierdzi, że dysponuje taką wiedzą, i że „potrafi owym algorytmem boskim się posłużyć i okazać, że taki czy inny poszczególny fakt zła i cierpienia, jakkolwiek byłby straszliwy, jest przy bliższym wejrzeniu dobry w nieskończenie globalnym bilansie, bo każdy taki fakt albo większe zło uniemożliwia, albo umożliwia większe dobro. Bilans tylko Bogu jest znany, my nie możemy starać się - beznadziejnie - o jego odtworzenie. Nie mamy zresztą pojęcia, jak można by mierzyć i ilościowo porównywać poszczególne rodzaje zła i dobra w ich rozmaitości nieskończonej”39. Człowiekowi, który nie ma możliwości przeniknięcia Bożych zamysłów, i poznania metody, którą posługuje się Stwórca obliczający optymalne proporcje pomiędzy dobrem i złem, pozostaje jedynie całkowicie zaufać Jego planom i zaakceptować je bez żadnych wcześniejszych kalkulacji i bez skarg na swój los.

W ostatecznym rozrachunku to właśnie bezwarunkowa wiara w Bożą dobroć jest jedynym sensownym uzasadnieniem idei świata najlepszego z możliwych, a wszystkie inne argumenty Leibniza zapisane na kartach Teodycei są jedynie mało istotnym dodatkiem, który wcześniej czy później musi doprowadzić do wniosku o konieczności całkowitego zawierzenia Bogu. Nie da się

\footnotetext{
${ }^{37}$ Por. Z. Pucko, Czy cierpienie ma sens? Teodycea wobec bólu i cierpienia, Kraków 2004, s. $31-40$.

${ }^{38}$ „A wy, którzy twierdzić śmiecie, że »dobre jest cokolwiek się zdarzy na świecie«, [...] Cóż to! Więc na świecie bez zniszczenia Lizbony gorzej by się działo?"; Wolter, Poemat o zagładzie Lizbony, przeł. A. Wołowski, „Literatura na Świecie”, 1979, 4 (96), s. 326.

${ }^{39}$ L. Kołakowski, Leibniz i Hiob. Metafizyka zła i doświadczenie zła, [w:] tenże, Czy Pan Bóg jest szczęśliwy i inne pytania, Kraków 2009, s. 11-12.
} 
bowiem udowodnić tego, że Stwórca powołał do istnienia najlepszy z możliwych światów. Jest to jedno z tych twierdzeń z pogranicza teologii i filozofii, które trzeba przyjąć na wiarę. Czy Leibniz rzeczywiście wierzył w to, że żyje w świecie najlepszym z możliwych, i że wszystko, co go w życiu spotyka, jest realizacją najlepszego scenariusza, jaki mógł napisać Bóg? Łatwo było mu wierzyć w to wtedy, gdy jeszcze był zdrowy, i gdy rozważał kolejne argumenty swojej teodycei, pełniąc funkcję dworskiego filozofa u boku królowej Zofii Karoliny. Jednak po jej śmierci Leibniz szybko utracił przychylność dworu i przestał bywać na salonach. Przez kilka ostatnich lat życia coraz bardziej dokuczał mu artretyzm (dna moczanowa), który początkowo jedynie utrudniał chodzenie, ale później - około roku 1714 - do tego stopnia zaatakował stopy, ręce i ramiona, że Leibniz nie mógł już normalnie pracować. Na prawej nodze filozofa pojawiła się otwarta, krwawiąca rana, która w krótkim czasie całkowicie uniemożliwiła chodzenie. Zaczął również coraz częściej cierpieć z powodu bolesnych ataków kamieni nerkowych. Ostatnie tygodnie swojego życia Leibniz spędził w łóżku, usiłując domowymi sposobami (na to, by odwiedził go lekarz, zgodził się dopiero w przeddzień swojej śmierci) ograniczyć ból spowodowany postępami choroby ${ }^{40}$. Czy również wtedy wierzył w to, że męczący go artretyzm, ropiejąca rana na nodze i boleśnie odczuwane ataki kamieni nerkowych są konieczne do tego, by stworzony przez Boga świat rzeczywiście był światem najlepszym z możliwych? Tylko on sam znał odpowiedź na to pytanie.

Osamotniony i zapomniany przez tych, którym wiernie służył jako dyplomata i dworski filozof, Leibniz zmarł w 14 listopada 1716 roku w Hanowerze. Na jego pogrzebie nie zjawił się nikt z zaproszonych dworzan, a przy złożeniu ciała do grobu był obecny jedynie jego osobisty sekretarz i kilka usługujących mu osób. „Wszystko to nie spowodowało jednak żadnych zmian w zasadach działania wszechrzeczy - zauważa trzeźwo autor wstępu do polskiego wydania Teodycei - albowiem także wówczas, gdy po życiu pełnym świetności umiera w opuszczeniu i zapomnieniu największy z optymistów, najdoskonalszy z możliwych światów pozostaje w swej istocie taki sam jak był poprzednio" ${ }^{41}$.

${ }^{40}$ Zob. B. Mates, The Philosophy of Leibniz. Metaphysics and Language, Oxford 1989, s. 29-30.

${ }^{41}$ J. Kopania, Siła dedukcji i słabość człowieka. Tragiczny optymizm Leibniza, s. XXVIII. 


\section{Bibliografia}

Augustyn Św., O naturze dobra, przeł. M. Maykowska, [w:] tenże, Dialogi i pisma filozoficzne, Warszawa 1954, s. 169-201.

Die philosophischen Schriften von G. W. Leibniz, red. C. I. Gerhardt, Berlin 1875-1890. Gut P., Leibniz. Myśl filozoficzna XVII wieku, Wrocław 2004.

Heller M., Ostateczne wyjaśnienia wszechświata, Kraków 2008.

Kołakowski L., Leibniz i Hiob. Metafizyka zła i doświadczenie zła, [w:] tenże, Czy Pan Bóg jest szczéśliwy i inne pytania, Kraków 2009, s. 11-12.

Kołakowski L., Jeśli Boga nie ma..., Kraków 1988.

Kopania J., Siła dedukcji i słabość człowieka. Tragiczny optymizm Leibniza, [w:] G. W. Leibniz, Teodycea. O dobroci Boga, wolności człowieka i pochodzeniu zła, przeł. M. Frankiewicz, Warszawa 2001, s. VII-XXVIII.

Leibniz G. W., O ostatecznym źródle rzeczy, [w:] tenże, Główne pisma metafizyczne, przeł. S. Cichowicz, J. Domański, Toruń 1995.

Leibniz G. W., Pisma z teologii mistycznej, przeł. M. Frankiewicz, Kraków 1994.

Leibniz G. W., Teodycea. O dobroci Boga, wolności człowieka i pochodzeniu zła, przeł. M. Frankiewicz, Warszawa 2001.

Leibniz G. W., Wyznanie wiary filozofa, Rozprawa metafizyczna, Monadologia, Zasady natury $i$ łaski, oraz inne pisma filozoficzne, przeł. S. Cichowicz, Warszawa 1969.

Mates B., The Philosophy of Leibniz. Metaphysics and Language, Oxford 1989.

Palacz R., Klasycy filozofii, Warszawa 1987.

Planck M., Zasada najmniejszego działania, [w:] tenże, Nowe drogi poznania fizycznego a filozofia, przeł. K. Napiórkowski, Warszawa 2003.

Pucko Z., Czy cierpienie ma sens? Teodycea wobec bólu i cierpienia, Kraków 2004.

Wolter, Poemat o zagładzie Lizbony, przeł. A. Wołowski, „Literatura na Świecie”, 1979, 4 (96), s. 319-332.

Wolter, Kandyd czyli optymizm, przeł. T. Żeleński-Boy, Kraków 2009.

\section{Abstract \\ Gottfried Wilhelm Leibniz's Idea of the Best of All Possible Worlds}

This article deals with the idea of the best possible world which was proposed by German philosopher Leibniz. He is regarded as a creator of theodicy - a philosophical discipline that is searching for some arguments to defend God against accusations of evil present in the created world. One of such arguments is included in Leibniz's thesis that all the possible worlds exist potentially in the mind of God, and from 
this infinite collection of possibilities God chooses the best option and calls it into being. What is important is that the best of all possible worlds is not a perfect world devoid of evil. Such a world cannot exist because it is internally contradictory. It is the best possible world in a sense that it's an optimal configuration of things and events, which contains maximum of the possible good and minimum of the inevitable evil. In this paper the main points of Leibniz's argumentation that concern this issue are presented and critically analysed.

Key words: the best of all possible worlds, Leibniz, the problem of evil, theodicy 